\title{
Preface
}

Individual Chicano gang members' private, personal backgrounds and motivations are the subject of this book. Neighborhood and home realities and the ineffective influences of several social institutions have made these members seek the street gang as a source of identity and support. There are multiple crises and turning points in the trajectories of their lives, which, in turn, have created voids that must be replaced by something. That something is the gang.

Analysts and practitioners familiar with delinquency have long argued that early childhood experiences predict intense gang involvement during adolescence and young adult years. The life histories of this study illuminate this process and shed some light on the background reasons for the differences among various types of gang members. In addition to this descriptive account of the commonalities of gang members' backgrounds and the dynamic conditions that facilitate gang forms and gang membership, this study also makes a preliminary examination of what interconnections there are among several factors. A historical and structural interpretation suggests that residence in isolated and physically distinct barrio enclaves and a low-income life, especially for the most impoverished underclass members, makes for particularly troublesome ecological and economic problems. Repercussions from such conditions, in turn, generate social and cultural strains and stresses that make the youth within this segment more at risk to an orientation to street life. In fact, when home life becomes overly problematic, it is the streets that become the main socialization agent in their lives.

Much of the gang patterns and behaviors can be largely attributed to the realities of the streets. Ways of acting and thinking are fashioned to aid coping with the streets. An institutionalized way of life is now firmly rooted in many Mexican American enclaves and the "cholo front" (e.g., dress, talk, gestures), street rituals (e.g., initiation, gang warfare), and symbols (e.g., tattoos, graffiti) comprise the primary source of identity for many youth. In short, the creation and perpetua- 
tion of a Chicano gang subculture is the end product of various interrelated influences that give rise to, and provide a means for dealing with, specific problems of identity in certain youths.

The assistance and participation of untold numbers of people made this study possible; they represent various roles and perspectives both within and outside the barrio and gang life. The strongest and most obvious contributions were from the gang members themselves and other cholos and street youths. They include individuals I have known on the streets from my youth and as a gang worker and watcher over several generations and, particularly, the contemporary populations that constitute the bulk of the life histories and observed street dynamics of this study. To them and all cholos of the barrios of Southern California, I hope I accurately and fairly depicted what this street reality is all about-warts and all.

A special expression of thanks is also extended to the many students at Chaffey College in Rancho Cucamonga, where I taught for over ten years, who were my field researchers and key informants. Denise Miller, Carole Edens, and Jessie Ortega (né Deputy) come especially to mind for their long-term participation and contributions. In addition, students in a Chicano Studies seminar at California State University, Los Angeles (1980), contributed invaluable insights on East Los Angeles gangs. My advisors in graduate school at UCLA, Tom Weisner and Pete Snyder, are greatly appreciated for their guidance in my early gang research; and Robert Edgerton for writing the foreword.

Individuals and families from Cucamonga deserve special praise in their always open and constant efforts to aid the undertaking, as they enthusiastically felt, as did residents from other barrios, that the "record on gangs should be made straight." Space does not permit me to give all their names, but some of them are Luis and Roseann Gonzales, Don Reyes, Mary Nuñez, Romelia Olivas, and Miguel and Manuel Nicasio.

The researchers and staff of the Chicano Pinto Research Project (now Community Systems Research, Inc.) were also instrumental in providing insights and data to guide the purpose of the study, especially Joan Moore, Robert García, and John Long. Their longitudinal and multidimensional look (over nearly fifteen years) at El Hoyo Maravilla and White Fence, two long-standing urban barrios, have provided in-depth historical evidence of gang dynamics. In addition to this help, Joan and Burt Moore read earlier versions of the study and offered instructive criticisms and suggestions. Particularly helpful in this regard is the critical and editorial advice that John $\mathrm{M}$. Long has provided throughout all phases of the research and writing. 
Finally, the opportunities to gain insight from various levels of criminal justice and educational systems were aided by a number of people, namely, David Tristan, Chuck Pineda, Fred Martinez, Al Ortiz, Steve López, and Pete de la Peña of the Gang Violence Reduction Project; Al Villanueva and Harold "Wardie" Walker from the Nelles School for Boys; Mike Duran, Aaron Rosenthal, and Ramiro Castillo from the Probation Department; Bob Eicholtz and Dick Torres from Pioneer High School in Pico-Rivera; David Brooks and Frank Garcia from Glenn High School in Norwalk; and Sergeants Wes McBride and Richard Valdemar from the Sheriff's Operation Safe Streets (OSS) program.

Partial support for this research was provided by a NIMH fellowship (F 32 HM0795-01), a sabbatical leave by Chaffey College, and an independent study grant from the Ford Foundation during overlapping periods in 1979 and 1980. Estella Tilley and Mae Horie deserve my heartfelt thanks for having contributed many hours typing various versions of the book. My wife Polly was most patient and helpful throughout all the years of my research and writing, and to her a special embrace of appreciation. Also, my son, James, and daughter, Joan, are appreciated for the general remarks they made. While all the above are credited for facilitating and informing the study, I am solely responsible for the collection and filtering of facts and analytical interpretations. 
THIS PAGE INTENTIONALLY LEFT BLANK 


\section{Barrio Gangs}

Street Life and Identity in Southern California 
THIS PAGE INTENTIONALLY LEFT BLANK 